\title{
APLIKASI MONITORING SERVER DAN ANALISIS KUALITAS MENGGUNAKAN MODEL ISO 9126
}

\author{
Triyadi \\ Program Studi Informatika,Universitas Indraprasta PGRI \\ Triyadi170@gmail.com
}

Submitted February 27, 2020; Revised March 23, 2020; Accepted March 26, 2020

\begin{abstract}
Abstrak
Server berperan sangat penting dan pada kenyataannya tidak pula selalu berjalan dengan baik tanpa adanya gangguan baik gangguan pada hardware maupun software didalamnya, dan diperlukan penanganan yang khusus dan cepat untuk menghadapi permasalahan tersebut. Penelitian ini bertujuan untukmenghasilkan perangkat lunak monitoring serverdengan menguji kualitas perangkat lunak menggunakan standar ISO/IEC 9126 yang meliputi aspek functionality, efficiency, reliability, dan usability.Metode penelitian yang digunakan adalah Research and Development (R\&D) dengan model pengembangan Rapid Application Development (RAD) yang terdiri dari Perencanaan Syarat-syarat, Workshop Design dan Fase Implementasi. Hasil pengujian dari aplikasi monitoringserver diperoleh nilai functionality pada kategori baik atau memenuhi aspek functionality, pengujian aspek efficiency menggunakan Yslow diperoleh hasil pada Grade A, pengujian aspek reliability menggunakan WAPT 8.5 didapat nilai reliability pada kategori baik atau memenuhi aspek reliability, dan pengujian aspek usability diperoleh hasil pada kategori baik.

Kata Kunci:ISO 9126,MonitoringServer,RapidApplication Development
\end{abstract}

\begin{abstract}
Server's role is very important. However, in reality, server does not run well because there are always disruption or disturbance in its hardware and software, requiring special and prompt handling them. The purpose of this research is to produce a server monitoring software by testing the quality of the software based on the standard ISO/IEC 9126 on the aspects of functionality, efficiency, reliability, and usability. The research uses a Research and Development $(R \& D)$ method with the development model of Rapid Application Development (RAD) consisting of Planning terms, Workshop Design and Implementation Phase. The result of test on the server monitoring application show that the functionality score is in a good category or fulfills the aspects of functionality and the test on aspects of efficiency using YSlow results in Grade A. The test on aspects of reliability using WAPT 8.5 reliability shows that the reliability score is in a good category or fulfills the aspects of reliability and the test on aspects of usability results in a good category.
\end{abstract}

Keywords:ISO 9126,MonitoringServer,RapidApplication Development

\section{PENDAHULUAN}

Kebutuhan akan kualitas kinerja server yang baik pada perusahaan sangat diharapkan, hal ini berkaitan dengan peranan server sebagai sistem komputer pusat yang melayani dan mengelola banyak pengguna maupun sumber daya dalam suatu jaringan server [1].

Sedemikian pentingnya peranan server, pada kenyataanya tidak pula selalu berjalan dengan baik tanpa adanya gangguan, baik gangguan pada hardware maupun software didalamnya.

Ada banyak hal yang menjadi penyebab tidak dapat diaksesnya suatu server website, seperti terjadinya kerusakan perangkat keras server ataupun kerusakan pada program perangkat lunak server. Server bersifat realtime atau waktu nyata sehingga kinerja server diawasi oleh 
seorang administrator sistem yang bertugas mengelola, dan menangani setiap permasalahan yang terjadi dalam waktu 24 jam. Seorang admininisrator juga bertanggung jawab memastikan ketersediaan aplikasi, baik bagi pengguna ataupun bagi server sendiri [2].

Berdasarkan masalah tersebut, maka diperlukan perangkat lunak yang dapat menampilkan kondisi real-time sebuah server website yang dapat memberikan notifikasi jika server website mengalami down atau tidak bisa diakses, sehingga memudahkan administrator dalam memonitor server untuk di tindak lanjuti.

Tujuan dari penelitian ini adalah untuk mengembangkan perangkat lunak monitoring server dengan menguji kualitas perangkat lunaknya menggunakan standar ISO/IEC 9126 yang telah diidentifikasi [3] dalam WebQEM yang meliputi aspek functionality, efficiency, reliability, dan usability.

Banyak model yang dapat digunakan untuk mengukur kualitas perangkat lunak, salah satunya adalah ISO 9126 yang merupakan gabungan dari beberapa standar kualitas yang telah ada. Standar ini dikembangkan dengan tujuan untuk mengidentifikasi beberapa aspek dalam aplikasi agar dapat diketahui kesesuaian dengan kaidah kualitas perangkat lunak.

\section{METODE PENELITIAN}

Penelitian ini dilakukan di perusahaan yang bergerak dalam bidang teknologi informasi dan penelitian yang dilakukan merupakan jenis Penelitian Research and Development (R\&D) yang digunakan untuk menghasilkan produk tertentu dan menguji produk tersebut [4]. Hasil penelitian dapat langsung diterapkan untuk memecahkan permasalahan yang dihadapi.

\section{Pengumpulan Data}

Kajian teori yang dilakukan dengan mengumpulkan data dan informasi dari berbagai sumber seperti buku, jurnal maupun artikel yang ada di internet tentang teori-teori yang berhubungan dan erat kaitannya dengan dengan penelitian ini. Metode observasi atau pengamatan langsung juga dilakukan terhadap organisasi dan obyek penelitian. Wawancara dengan pihak-pihak yang berkaitan dengan penelitian. Dalam wawancara tersebut peneliti telah menyiapkan daftar pertanyaan yang berkaitan dengan pengembangan Software Aplikasi. Questioner digunakan pada saat menguji kualitas system dari aspek functionality dan usability sistem. Pada kuesioner functionality menggunakan kuesioner checklist, karena aspek yang dinilai dalam funcionality terdiri dari fungsi-fungsi, masukan, dan keluaran dari sistem perangkat lunak yang bersifat fisik sehingga hanya memerlukan jawaban "Ya" atau "Tidak". Sedangkan kuesioner untuk usability menggunakan USE Questionnaire yang merupakan instrumen yang dapat digunakan untuk mengevaluasi aspek usability sebuah perangkat lunak. Pengambilan sampel untuk usability dengan purposive sampling yang merupakan teknik pengambilan sampel dengan mengambil responden yang terpilih betul oleh peneliti menurut ciri-ciri spesifik yang dimiliki oleh sampel tersebut.

\footnotetext{
Alur Penelitian

Pada tahap pertama penelitian yang di lakukan adalah mengembangkan konsep penelitian dengan observasi dan kajian teori, kemudian pada tahap selanjutnya yaitu perencanaan, rancangan dan implementasi sistem menggunakan metode Rapid Application Development (RAD) dan pada tahap pengujian menggunakan model ISO 9126.
} 


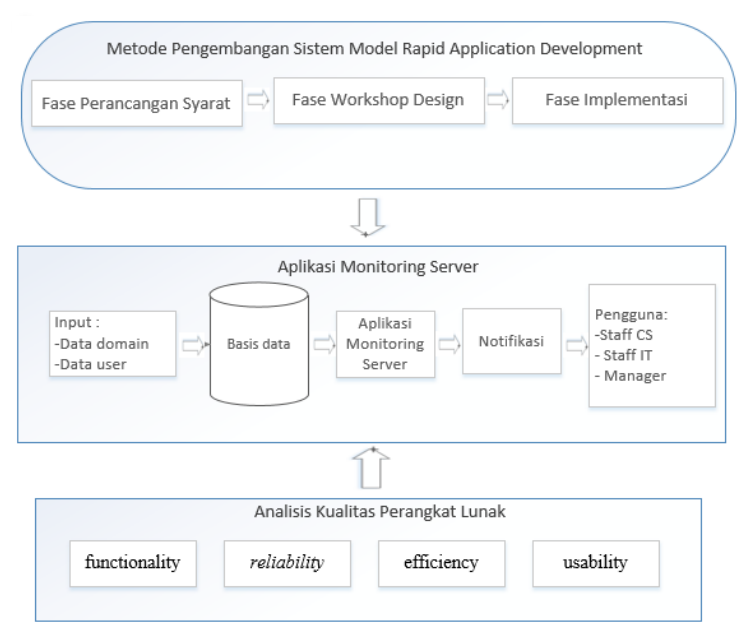

Gambar 1. Alur Penelitian

1. Peneliti mengembangkan aplikasi menggunakan metode Rapid Application Development (RAD) yang terdiri dari 3 fase yaitu fase perencanaan syarat-syarat, fase workshop design, dan fase implementasi.

2. Aplikasiyang telah dikembangkan kemudian di implementasi pada lingkungan live production yang dapat diakses oleh pengguna sistem sesuai dengan batasan-batasan level pengguna dan telah melewati pengujian blackbox testing terhadap sistem yang telah dikembangkan.

3. Dilakukan pengujian pada aplikasi dengan menggunakan standar kualitas perangkat lunak menurut ISO 9126 pada beberapa aspek. Aspek-aspek tersebut adalah aspek functionality, reliability, effisiensy, dan usability dengan tujuan untuk mengidentifikasi kesesuaian dengan kaidah kualitas perangkat lunak.

\section{HASIL DAN PEMBAHASAN}

\section{Pengembangan Sistem}

Pengembangan dilakukan mengacu pada model pengembangan prototype. Paradigma prototype dimulai dari identifikasi masalah yang dilanjutkan desain dan pengembangan yang berfokus pada pengguna. Prototype yang dihasilkan selanjutnya dievaluasi pengguna. Proses ini akan berulang sehingga model pengembangan ini secara keseluruhan mengacu pada kepuasan pengguna. Model pengembangan prototype mengimplementasikan beberapa bagian fungsi dari perangkat lunak yang sesungguhnya.

\section{A. Perencanaan Syarat-syarat}

Pada fase ini peneliti mengidentifikasikan tujuan-tujuan aplikasi atau sistem serta berdasarkan permasalahan yang ada serta mengidentifikasi requirement yang ditimbulkan dari tujuan-tujuan sistem tersebut dengan menganalisa sistem yang sedang berjalan dan dengan menentukan fitur-fitur dan modul aplikasi.

1. Menampilkan status host yang dimonitoring. Informasi yang ditampilkan meliputi:

a. Status ketersediaan host pada jaringan apakah onlineatau offline.

b.Detail informasi mengenai hostyang meliputi nama host, alamat IP.

c.Catatan waktu perubahan kondisi pada host

2. Menampilkan catatan uptime dari host yang dimonitoring.

3. Sistem pencatatan log status host.

4. Pengaturan notifikasi perubahan keadaan host pada server melalui SMS.

5. Pengaturan grup untuk menerima notifikasi perubahan keadaan host pada server melalui SMS

6. Pengelolaan user dan hak aksesnya.

Modul yang akan dibuat adalah sebagai berikut:

1. Mengelola User, untuk melakukan aktifitas penambahan, perubahan dan penghapusan user dan hak aksesnya dan menampilkan daftar user yang ada di sistem monitoring. 
2. Mengelola domain, untuk melakukan aktifitas penambahan, perubahan, dan penghapusan hostserver.

3. Memonitoring Server website, untuk melakukan aktifitas monitoring dan mengirimkan notifikasi jika terjadi masalah.

4. Mengelola notifikasi phonebook, untuk melakukan pengaturan notifikasi melalui SMS. Selain itu juga dipakai untuk melihat SMS $\log$ notifikasi serta untuk melakukan penambahan, perubahan, penghapusan nomor tujuan notifikasi.

5. Mengirimkan dan menerima notifikasi SMS, untuk mengirimkan pesan notifikasi kepada penerima notifikasi.

\section{B. Fase Workshop Design}

\section{Perancangan UML}

UML (Unified Modeling Language) merupakan bahasa pemodelan berorientasi objek yang digunakan untuk menentukan, memvisualisasikan, dan mendokumentasikan suatu sistem informasi. UML direpresentasikan dengan beberapa diagram, salah satu diantaranya adalah usecase diagram.

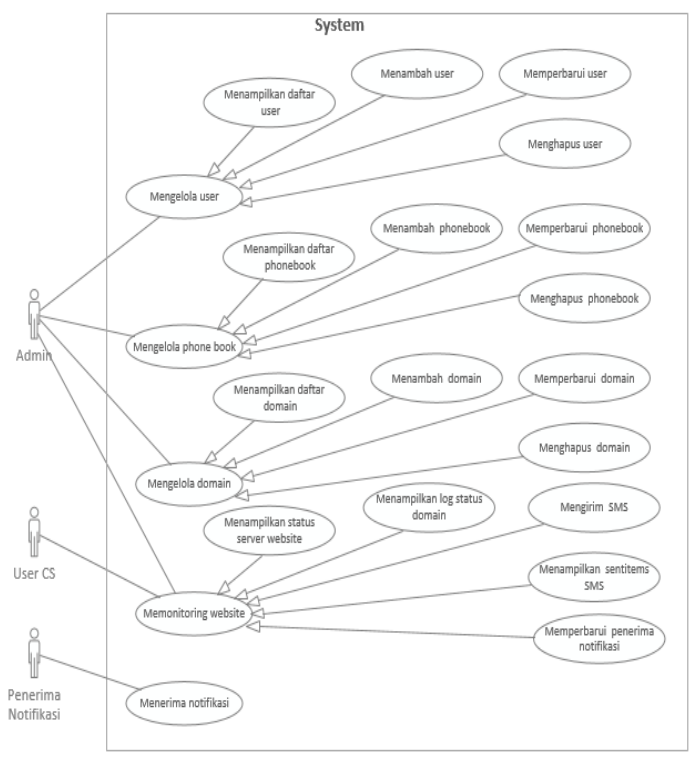

Gambar 2. Usecase Diagram
Pada gambar 2 merupakan Use Case diagram yang menggambarkan semua actor dengan skenario masing-masing.

\section{Perancangan Database}

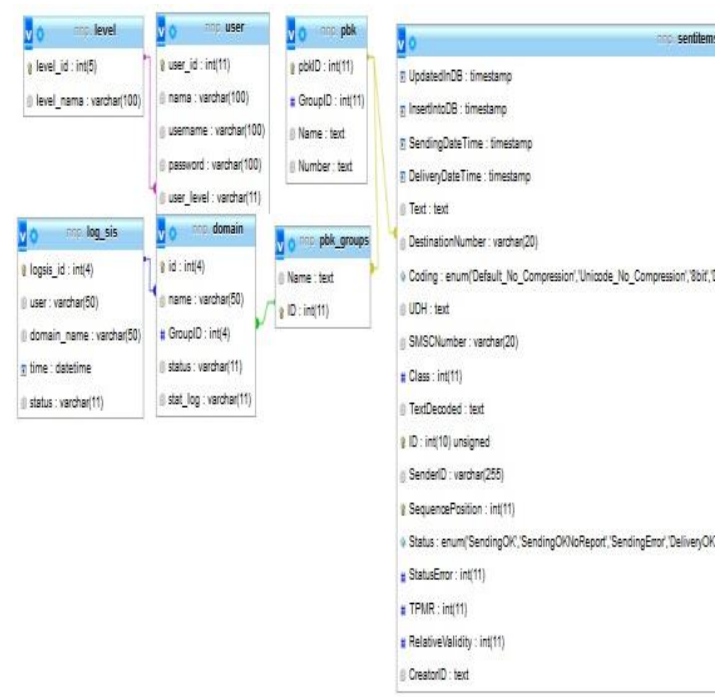

Gambar 3. ER Diagram

Pada gambar 3 merupakan Entity relationship (ER) diagram yang menggambarkan hubungan antar data dalam basis data yang mempunyai relasi.

\section{Perancangan Interface}

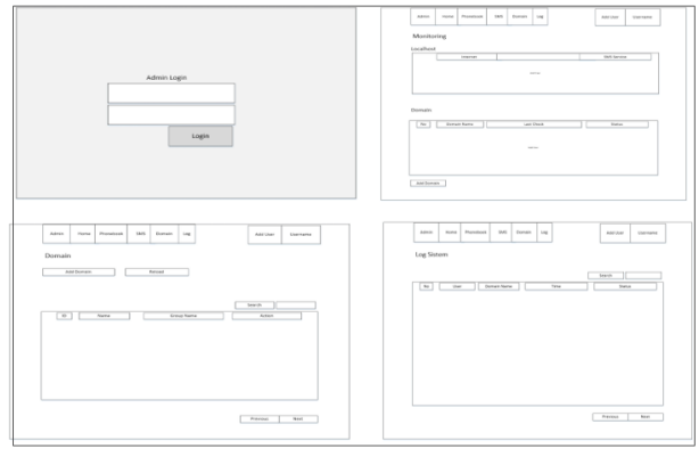

Gambar 4. Desain halaman

Pada gambar 4 merupakan desain tampilan pada halaman login, home, domain dan log sistem pada sisi admin. 


\section{Fase Implementasi}

\section{Instalasi Aplikasi Monitoring}

Instalasi aplikasi monitoring server pada server internal yang menggunakan OS linux centos dan untuk webserver menggunakan LAMPP.

Modul modul yang terdapat pada aplikasi monitoring server di instalasi pada webserver diantaranya yaitu modul login, home, phonebook, SMS, domain, log sistem dan add user.

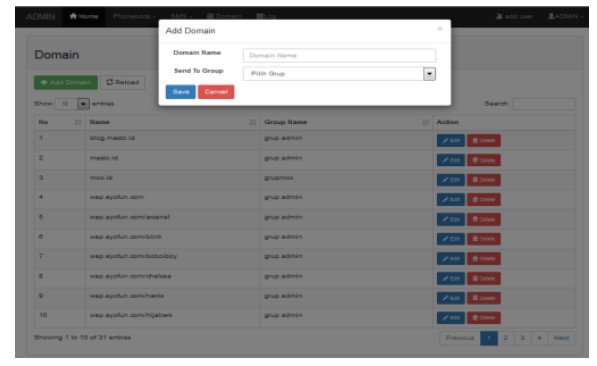

Gambar 5. Tampilan halaman Domain

Pada gambar 5 merupakan salah satu tampilan halaman yang terdapat pada aplikasi monitoring server yaitu halaman domain yang berfungsi untuk menginput ataupun mengedit informasi data nama domain yang akan di monitoring.

\section{Pengujian Sistem}

Pengujian sistem dilakukan pada aspek functionality, reliability, usability, dan efficiency.Aspek reliability, dan efficiency akan diuji menggunakan tools yang menyediakan fasilitas untuk pengujian aplikasi berbasis web sedangkan pada aspek functionality dan usability pengujian dilakukan menggunakan kuesioner.

\section{1) Functionality}

Pengujian pada aspek functionality dilakukan menggunakan angket kuisioner yang berisi checklist pada testcase yang berisi daftar fungsi sistem yang dijabarkan sesuai analisis kebutuhan dan dilakukan oleh 3 orang ahli yang memiliki pekerjaan sehari-hari di bidang pengembangan web maupun pemrograman seperti pada tabel 1 .
Tabel 1. Hasil Pengujian Aspek Functionality

\begin{tabular}{|c|c|c|c|}
\hline \multirow{2}{*}{ Checklist user } & \multicolumn{2}{|c|}{ Test case fungsi } & \multirow{2}{*}{$\begin{array}{c}\text { Total Test } \\
\text { Case }\end{array}$} \\
\hline & Sukses & Gagal & \\
\hline $\begin{array}{l}\text { Checklist test } \\
\text { case user } 1\end{array}$ & 25 & 0 & 25 \\
\hline $\begin{array}{l}\text { Checklist test } \\
\text { case user } 2\end{array}$ & 25 & 0 & 25 \\
\hline $\begin{array}{l}\text { Checklist test } \\
\text { case user } 3\end{array}$ & 25 & 0 & 25 \\
\hline Total & 75 & 0 & 75 \\
\hline
\end{tabular}

Berdasarkan hasil pengujian tersebut diketahui tingkat fungsionalitas sistem menggunakan rumus analisis data ISO/IEC TR 9126-2. X merupakan Functionality, dimana $\mathrm{A}$ adalah jumlah total fungsi yang tidak valid dan $\mathrm{B}$ adalah jumlah seluruh fungsi.

$$
\begin{aligned}
& X=1-\frac{A}{B} \\
& X=1-\left(\frac{0}{75}\right)=1
\end{aligned}
$$

Sesuai dengan interpretasi ISO/IEC TR 9126-2, nilai functionality dikatakan baik jika nilai perhitungan mendekati 1 . Dari hasil perhitungan tingkat functionality sistem informasi yang dikembangkan, menunjukkan jumlah total fungsi yang tidak valid adalah 0 sedangkan nilai jumlah seluruh fungsi adalah 75 dan di dapat kan nilai functionality (X) sebesar 1.

\section{2) Efficiency}

Pengujian aspek efficiency dilakukan untuk menguji performa dan kecepatan akses sebuah halaman web. Pengujian dilakukan menggunakan tool YSlow. Pada pengujian aspek efficiency yang telah dilakukan di dapatkan skor berupa grade yang menunjukkan nilai performance secara keseluruhan terhadap komponen yang diuji. 
Tabel 2. Rekapitulasi Data Pengujian Efficiency dengan Yslow

\begin{tabular}{|lccc|}
\hline Halaman & $\begin{array}{c}\text { Overall } \\
\text { performance } \\
\text { score }\end{array}$ & $\begin{array}{c}\text { Score } \\
\text { max }\end{array}$ & Grade \\
\hline Halaman Login & 96 & 100 & A \\
Halaman Home & 96 & 100 & A \\
Halaman Phonebook & 98 & 100 & A \\
HalamanPhonegroup & 98 & 100 & A \\
Halaman Sendsms & 98 & 100 & A \\
Halaman Sentitems & 98 & 100 & A \\
Halaman Domain & 98 & 100 & A \\
Halaman Log & 98 & 100 & A \\
Halaman User & 98 & 100 & A \\
Halaman Profil & 94 & 100 & A \\
Total & $\mathbf{9 7 2}$ & $\mathbf{1 0 0 0}$ & \\
\hline
\end{tabular}

Berdasarkan hasil rekapitulasi seperti pada tabel 2, dilakukan perhitungan untuk mendapatkan persentase skor pada aspek efficiency sebagai berikut :

Persentase Kelayakan (\%)

$$
=\frac{\text { Skor yang diobservasi }}{\text { Skor yang diharapkan }} \times 100 \%
$$

Persentase Kelayakan (\%)

$$
=\frac{972}{1000} \times 100 \%=97.2 \%
$$

Hasil pengujian pada aspek efficiency seperti pada tabel 2 menggunakan tool Yslow menunjukkan total skor yang diobservasi adalah 972 sedangkan skor yang diharapkan adalah 1000 dan di dapatkan persentase overall performance score adalah $97.2 \%$ dan mendapat Grade A.

\section{3) Reliability}

Pengujian aspek reliability dilakukan dengan menggunakan tool atau software WAPT 8.5. Tool ini akan melakukan stress testing dengan menggunakan simulasi useractive dan koneksi yang kontinu terhadap sistem aplikasi monitoring berbasis web yang dites untuk mendapatkan success rate dan failure rate. Pengujian dilakukan meliputi beberapa parameter seperti sessions, pages, dan hits. Berdasarkan hasil pengujian tersebut maka dapat direkap dalam bentuk tabel seperti berikut :

Tabel 3. Pengujian Aspek Reliability Menggunakan WAPT 8.5.

\begin{tabular}{|cccc|}
\hline Metrik & Sukses & Gagal & Total Case \\
\hline Sessions & 16 & 0 & 16 \\
Pages & 394 & 0 & 394 \\
Hits & 603 & 0 & 603 \\
Total & 1013 & 0 & 1013 \\
\hline
\end{tabular}

Berdasarkan hasil tersebut maka reliabilitas dari aplikasi monitoring dapat dihitung menggunakan rumus perhitungan nilai reliability [5].

$\mathrm{R}=1-\frac{f}{n}=1-\frac{0}{1013}=1$

R merupakan Reliability sedangkan $f$ adalah Total failure dengan nilai yang didapatkan 0 dan $\mathrm{n}$ adalah Total test cases dengan nilai yang didapatkan 1013 .

Berdasarkan Telcordia Standar R3-34 dalam GR 282 "Software Reliability and Quality Acceptance Criteria" menetapkan bahwa hasil pengujian dikatakan memenuhi aspek reliability jika persentase dari test case yang dijalankan bernilai minimal $95 \%$ atau 0,95. Berdasarkan hasil dari pengujian aspek reliability menggunakan WAPT 8.5, hasil perhitungan model Nelson untuk aspek reliability aplikasi monitoring adalah 1 atau $100 \%$.

4) Usability

Pengujian pada aspek usability dilakukan menggunakan angket kuisioner USE Questionaire yang dikembangkan oleh STC Usability and User Experience Community dari Arlnold M. Lund dengan menggunakan skala Likert dan diberikan kepada responden yaitu karyawan yang sudah menggunakan aplikasi monitoring server seperti pada tabel 4 berikut ini: 
Tabel 4. Hasil Pengujian Usability

\begin{tabular}{|c|c|c|c|c|}
\hline \multirow{2}{*}{$\begin{array}{c}\text { Butir } \\
\text { Pertanyaan }\end{array}$} & \multicolumn{4}{|c|}{ Sebaran Jawaban } \\
\hline & SS & $\mathbf{S}$ & $\mathbf{K S}$ & TS \\
\hline 1 & 8 & 10 & 0 & 0 \\
\hline 2 & 4 & 14 & 0 & 0 \\
\hline 3 & 8 & 10 & 0 & 0 \\
\hline 4 & 9 & 9 & 0 & 0 \\
\hline 5 & 4 & 13 & 1 & 0 \\
\hline 6 & 6 & 12 & 0 & 0 \\
\hline 7 & 5 & 13 & 0 & 0 \\
\hline 8 & 3 & 15 & 0 & 0 \\
\hline 9 & 6 & 12 & 0 & 0 \\
\hline 10 & 7 & 11 & 0 & 0 \\
\hline 11 & 5 & 13 & 0 & 0 \\
\hline 12 & 5 & 13 & 0 & 0 \\
\hline 13 & 5 & 13 & 0 & 0 \\
\hline 14 & 4 & 14 & 0 & 0 \\
\hline 15 & 1 & 14 & 3 & 0 \\
\hline 16 & 2 & 16 & 0 & 0 \\
\hline 17 & 2 & 16 & 0 & 0 \\
\hline 18 & 1 & 17 & 0 & 0 \\
\hline 19 & 2 & 16 & 0 & 0 \\
\hline 20 & 2 & 15 & 1 & 0 \\
\hline 21 & 3 & 15 & 0 & 0 \\
\hline 22 & 5 & 12 & 1 & 0 \\
\hline 23 & 2 & 16 & 0 & 0 \\
\hline 24 & 3 & 15 & 0 & 0 \\
\hline 25 & 3 & 15 & 0 & 0 \\
\hline 26 & 3 & 15 & 0 & 0 \\
\hline 27 & 2 & 16 & 0 & 0 \\
\hline 28 & 1 & 17 & 0 & 0 \\
\hline 29 & 1 & 17 & 0 & 0 \\
\hline 30 & 3 & 15 & 0 & 0 \\
\hline Total & 115 & 419 & 6 & 0 \\
\hline
\end{tabular}

Berdasarkan hasil tersebut kemudian dihitung untuk menentukan interpretasi aspek usability :

Skor total $=$

$\left(J_{S S} \times 4\right)+\left(J_{S} \times 3\right)+\left(J_{K S} \times 2\right)+\left(J_{T S} \times 1\right)$

Skor total $=$

$(115 \times 4)+(419 \times 3)+(6 \times 2)+(0 \times 1)$

$=1729$
Skor total adalah total hasil dari responden menjawab pertanyaan yang terdiri dari jumlah responden sangat setuju (JSS), jumlah responden setuju (JS), jumlah responden kurang setuju (JKS) dan jumlah responden tidak setuju (JTS).

$$
\begin{aligned}
& \text { Pskor }=\frac{\text { skortotal }}{i \times r \times 4} \times 100 \% \\
& \text { Pskor }=\frac{1729}{2160}=80.05 \%
\end{aligned}
$$

skor merupakan nilai skortotal yang telah didapat dibagi hasil dari $i \times r \times 4$ dimana $i$ adalah jumlah dari pertanyaan yang di berikan sedangkan $r$ adalah jumlah responden yang menjawab pertanyaan.

Berdasarkan perhitungan persentase pengujian usability di atas, diperoleh hasil persentase pengujian adalah $80,05 \%$ dan berdasarkan hasil tersebut disesuaikan dengan kriteria interpretasi skor [6].

Pengujian usability juga dihitung nilai konsistensinya menggunakan software IBM SPSS Statistic dengan perhitungan alpha cronbach. Hasil perhitungan konsistensi dapat dilihat pada Gambar 6 berikut ini:

\section{Case Processing Summary}

\begin{tabular}{ll|r|r} 
& & \multicolumn{1}{c|}{$N$} & \multicolumn{1}{c}{$\%$} \\
\hline \multirow{2}{*}{ Cases } & Valid & 18 & 100,0 \\
\cline { 2 - 4 } & Excluded $^{\text {a }}$ & 0 &, 0 \\
\cline { 2 - 4 } & Total & 18 & 100,0 \\
\hline
\end{tabular}

a. Listwise deletion based on all variables in the procedure.

\section{Reliability Statistics}

\begin{tabular}{r|r}
$\begin{array}{c}\text { Cronbach's } \\
\text { Alpha }\end{array}$ & N of Items \\
\hline, 979 & 30 \\
\hline
\end{tabular}

Gambar 6. Hasil Perhitungan AlphaCronbach Menggunakan SPSS 
Berdasarkan perhitungan menggunakan software IBM SPSS Statistic tersebut didapatkan nilai alpha cronbach sebesar 0,979. Kemudian jika dibandingkan dengan tabel konsistensi alpha cronbach maka nilai konsistensi alpha cronbach menunjukkan kategori Excellent.

\section{SIMPULAN}

Berdasarkan hasil penelitian dan pembahasan yang telah dilakukan, dapat diambil kesimpulan yaitu model pengembangan aplikasi monitoring server ini menggunakan Rapid Application Development (RAD) yang terdiri dari Perencanaan Syarat-syarat, Workshop Design dan Fase Implementasi. Dalam hal monitoring, respon menjadi lebih cepat dilakukan karena adanya notifikasi Short Message Service (SMS) oleh sistem secara realtime jika terjadi masalah server down atau tidak dapat diakses. Uji kualitas aplikasi monitoring server menggunakan model ISO 9126 meliputi aspek functionality, efficiency, reliability, dan usability. Pada pengujian aspek functionality diperoleh nilai functionality pada kategori baik atau memenuhi aspek functionality, pengujian aspek efficiency menggunakan Yslow diperoleh hasil pada Grade A, pengujian aspek reliability menggunakan WAPT 8.5 didapat nilai reliability pada kategori baik atau memenuhi aspek reliability, dan pada pengujian aspek usability diperoleh hasil pada kategori baik.

\section{DAFTAR PUSTAKA}

[1] N. F. Asri, A. Hamzah, and M. Sholeh, "Nagios Untuk Monitoring Server Dengan Pengiriman Notifikasi Gangguan Server Menggunakan Email Dan Sms Gateway (Studi Kasus : PT. Gamatechno Indonesia Yogyakarta)," J. JARKOM, vol. 1, no. 2, pp. 151-161, 2014.

[2] T. D. Prayogo, K. Kushartantya, and H. A. Wibawa, "Sistem Monitoring Jaringan Pada Server Linux Dengan Menggunakan Sms Gateway," $J$. Masy. Inform., vol. 2, no. 3, pp. 6372, 2012.

[3] L. Olsina, G. Lafuente, and G. Rossi, "Specifying Quality Characteristics and Attributes for Websites," Murugesan S., Deshpande Y. Web Eng. Lect. Notes Comput. Sci., vol. 2016, pp. 266-278, 2001.

[4] Sugiyono, Metode penelitian kuantitatif,kualitatif, $R \& D, \quad 14$ th ed. Bandung: Alfabeta, 2011.

[5] L. S. Maurya and A. K. Malviya, "Web Application Reliability Assessment using Error and Workload Data Obtained from Server Error and Access Logs," Int. J. Comput. Appl., vol. 97, no. 15, pp. 6-9, 2014.

[6] Riduwan, Skala Pengukuran VariabelVariabel Penelitian, 9th ed. Bandung: Alfabeta, 2012. 